E Q U I L I B R I U M

1 (4) 2010

ISSN $1689-765 \mathrm{X}$

\title{
Lilianna Jodkowska
}

\section{Rynek pracy w Niemczech w latach 2000-2009. Zmiany form zatrudnienia}

Słowa kluczowe: rynek pracy, minijob, niskopłatne stanowiska pracy, praca tymczasowa

\begin{abstract}
Abstrakt: Celem opracowania jest przedstawienie sytuacji na niemieckim rynku pracy po roku 2000 przy zastosowaniu analizy danych i przedstawieniu ich graficznie oraz opisu nowych form zatrudnienia. Opracowanie składa się z 2 części, wstępu oraz zakończenia. W części pierwszej przedstawiona została sytuacja na rynku pracy pod kątem wskaźnika zatrudnienia oraz stopy bezrobocia w latach 2000-2009 przy uwzględnieniu przeprowadzonych reform zasiłków dla bezrobotnych (2005 r.). W części drugiej opracowania opisane zostały te nowe formy zatrudnienia (Minijob, niskopłatne stanowiska pracy, praca tymczasowa), które konkurują i wypierają w ostatnich latach zatrudnienie, stałe zapewniając pracodawcom niezbędną elastyczność, szczególnie ważną w dobie kryzysu. Opis tych form zatrudnienia poszerzony został o analizę zagrożenia ubóstwem wśród grup pracowników zatrudnionych na niskopłatnych i tymczasowych stanowiskach pracy. W zakończeniu zebrano najważniejsze wnioski opracowania.
\end{abstract}

\section{WPROWADZENIE}

Niski wzrost gospodarczy, wysoka stopa bezrobocia, a co za tym idzie zwiększająca się liczba odbiorców transferów społecznych utrzymujące się w latach 90 . XX w. doprowadziły do poszukiwania nowych rozwiązań - często bardziej rygorystycznych dla osób pobierających zasiłki. W czerwcu 1999 r. Tonny Blair i Gerhard Schröder podjęli próbę opracowania nowego programu państwa opiekuńczego zwanego „Trzecią drogą” (głoszącego potrzebę ograniczenia roli związków zawodowych i obecności państwa w gospodarce). W ramach „Trzeciej drogi”, a w Niemczech „Agendy 2000” wprowadzono zmiany w zakresie wysokości i okresu pobierania zasiłków dla bezrobotnych, a także wprowadzono obowiązek podejmowania przydzielonego bezrobotnemu przez Agencję Pracy 
zatrudnienia ${ }^{1}$. Obok reformy zasiłków dla bezrobotnych wprowadzono w zamierzony sposób nowe formy zatrudnienia. Ponadto od $1999 \mathrm{r}$. działały już pierwsze prywatne agencje pośrednictwa pracy, w 2002 r. zniesiono obowiązek posiadania licencji przez te agencje (rejestracja działalności gospodarczej jest wystarczająca). Wprowadziło to konkurencję między tymi usługodawcami i wywarło presję na jakość i koszt oferowanych usług (umowy o pracę na czas określony, niskie stawki godzinowe). Ze względu na presję kosztową i konkurencyjność na rynkach międzynarodowych oraz długie terminy wypowiedzeń przedsiębiorcy chętnie przyjęli oferowaną przez agencje pośrednictwa pracy tańszą siłę roboczą. Wysokie koszty pracy powoduja, że pracodawcy preferują rozwiązania kapitałochłonne, a nie pracochłonne (pracochłonne procesy przetwarzania przeprowadzane są w krajach o niższych kosztach produkcji, np. w krajach Europy Wschodniej - Por. K. Kurz, V. Wittke, 1998).

W niniejszym opracowaniu przedstawiono rozwój sytuacji na rynku pracy w Niemczech w latach 2000-2009 w zakresie niepełnoetatowych i niskopłatnych stanowisk pracy, które określane są jako „niepewne stosunki pracy” i niejednokrotnie przynoszą tak niski dochód, że są uzupełnianie transferami społecznymi.

\section{RYNEK PRACY W NIEMCZECH - ZATRUDNIENIE I BEZROBOCIE}

Liczba osób pozostających bez pracy wzrastała w Niemczech od lat 70. XX w. w czterech dziesięcioletnich cyklach, po upływie których przybywało po ok. milion osób bez pracy. Pierwszy cykl przypadł na lata 1970-1980, bezrobocie wzrosło w tym okresie o ok. 900000 osób. Drugi cykl to lata 1980-1991, w okresie tym przybyło ok. 700000 bezrobotnych. Trzecia dekada to lata 1992-2001, w zachodniej części Niemiec przybyło w tym okresie ok. 800000 bezrobotnych, we wschodniej ok. 1,5 mln. Czwarty cykl wzrostu bezrobocia rozpoczął się w roku 2002 i osiagnął szczyt na początku 2005 r., kiedy 5 mln osób pozostawało bez pracy. Po 2005 r. liczba osób bezrobotnych stale się zmniejszała i osiagnęła po raz pierwszy od lat 90 . XX w. jesienią $2008 \mathrm{r}$. rekordowo niską wartość - bez pracy pozostawało ok. 3 mln osób (od zimy 2008 r. zaczęła ponownie wzrastać ze względu na skutki globalnego kryzysu finansowego i gospodarczego). Średniorocznie w 2007 r. i 2008 r. bez pracy pozostawało 3,7 mln osób (co odpowiadało 8,5\% stopie bezrobocia) oraz 3,2 mln osób (7,5\%) (Statistisches Bundesamt, http://www.destatis.de).

Jedną z przyczyn utrzymywania się wysokiej stopy bezrobocia w latach 90 . $\mathrm{XX}$ w. była restrukturyzacja i likwidacja nierentownych przedsiębiorstw we

${ }^{1}$ Bezrobotni zobowiązują się w umowie, którą zawierają z Agencją Pracy do aktywnego poszukiwania nowego miejsc zatrudnienia. Niepodjęcie przydzielonego przez Agencję Pracy zatrudnienia sankcjonowane jest 10-30\% obniżeniem zasiłku na okres do kilku miesięcy. 
wschodniej części kraju. Na skutek zjednoczenia Niemiec przybyło ogółem nie tylko bezrobotnych, ale także osób czynnych zawodowo (włącznie z urzędnikami państwowymi, osobami prowadzącymi działalność gospodarczą oraz zatrudnionymi w pełnym i niepełnym wymiarze czasu pracy). W RFN liczba czynnych zawodowo kształtowała się od roku 1970 do 1989 na poziomie 26-27 mln. Po zjednoczeniu Niemiec liczba osób czynnych zawodowo waha się pomiędzy 37,5 mln i ok. 40,5 mln w 2008 r. (wzrost zwłaszcza po 2007 r. - wykres 1). Wartości te odpowiadają wskaźnikowi zatrudnienia grupy wiekowej 15-64 lata na poziomie $65 \%$ do $69 \%$.

Wykres 1. Zatrudnieni w Niemczech w latach 2000-2009

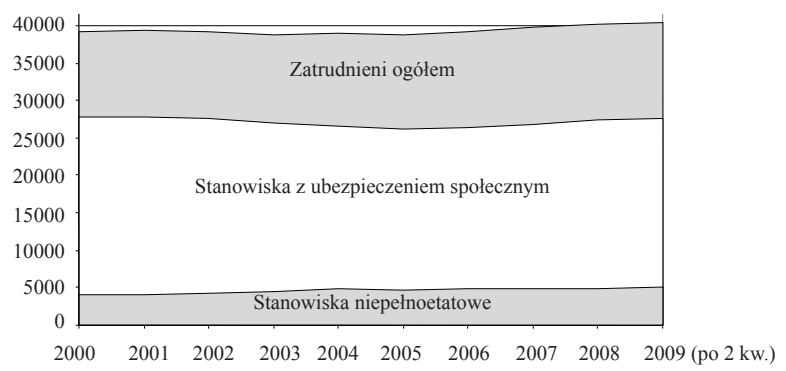

*zapis stanowisk niepełnoetatowych odbywa się od 1999 r.

Źródlo: Arbeitsmarkt 2007 (2008), Bundesagentur für Arbeit, Nürnberg; Der Arbeits- und Ausbildungsbericht für Deutschland. Monatsbericht September 2009, (2009), Bundesagentur für Arbeit.

W pierwszych latach XXI w. w ramach modernizowania roli i zadań państwa powołano inicjatywę pod hasłem ,aktywizująca rola państwa”, wyrażającą się m.in. w nałożeniu na bezrobotnych obowiązku aktywnego podjęcia poszukiwania pracy oraz pozostawania do dyspozycji odnośnych urzędów wypłacających zasiłek (obowiązek podjęcia każdej legalnej pracy przydzielonej bezrobotnemu przez Agencję Pracy, także w ramach tzw. minietatu (Minijob) lub pracy na niepełnym etacie). Jednocześnie przeprowadzono reformę zasiłków dla bezrobotnych. Do końca 2004 r. obowiązywały w Niemczech dwa różne zasiłki dla bezrobotnych (55-65\% dotychczasowej płacy brutto i wypłacane były na czas nieokreślony) oraz zasiłek socjalny ${ }^{2}$ (zapomoga), będący świadczeniem kwotowym. Od 1 stycznia 2005 r. utrzymano rozróżnienie na dwa rodzaje zasiłków

${ }^{2}$ Zasiłek socjalny (Sozialhilfe) wprowadzony został po raz pierwszy w 1924 r. i zreformowany w $1961 \mathrm{r}$. Po wprowadzeniu reformy Hartz IV zasiłek socjalny przysługuje wyłącznie osobom niezdolnym do pracy. Zasiłki socjalne są finansowane z podatków i przyznawane osobom powyżej 65 roku życia, które nie nabyły prawa do otrzymywania emerytury (Grundsicherung im Alter) oraz osobom od 18 roku życia niezdolnym do pracy. 
dla osób bezrobotnych (zasiłek dla bezrobotnych I i II / Arbeitslosengeld I i II), zmieniono jednak warunki ich przysługiwania oraz wysokość świadczeń. Podjęte w Niemczech starania ukierunkowane na zredukowanie liczby osób pozostających bez pracy korelują z celami wyznaczonymi przez Unię Europejską. Zainicjonowano m.in. programy dla bezrobotnej młodzieży oraz dla osób z grupy wiekowej powyżej 50 lat, dzięki którym nastąpiło obniżenie stopy bezrobocia w grupie wiekowej osób poniżej 25 lat z 11,8\% w 1998 r. do 9,1\% w 2004 r. i do ok. 7\% w 2008 r. Wzrósł także wskaźnik zatrudnienia osób ponad 50-letnich z 56,3\% w 2005 r. do 64,1\% w 2008 r. oraz kobiet - co wpływa korzystnie na wysokość późniejszych świadczeń emerytalnych. Doprowadzono także do wzrostu zatrudnienia osób powyżej 55 roku życia z 37,8\% w 1998 r. do 41,2\% w 2004 r. i do 51,5\% w 2008 r. (Sozialbericht 2005, s. 22; Statistisches Bundesamt, http://www.destatis.de). Zmniejszył się również udział osób długotrwale bezrobotnych (ponad 12 miesięcy bez pracy) w bezrobotnych ogółem z 43\% w 2006 r. do 36,6\% w 2008 r. (Sozialbericht 2009, s.17, 19), co przemawia za integracją wszystkich ww. wymienionych grup bezrobotnych na rynku pracy.

Korelacja pomiędzy wzrostem gospodarczym a poziomem bezrobocia w Niemczech jest znaczenie słabsza niż Polsce (por. Jodkowska, 2008). Tłumaczy to również sytuację na rynku pracy w 2009 r. - mimo dramatycznego załamania się eksportu napędzającego niemiecki wzrost gospodarczy i negatywnej wartości wzrostu gospodarczego po dwóch kwartałach 2009 roku stopa bezrobocia utrzymuje się na poziomie roku 2008 (wykres 2).

Wykres 2. Wzrost gospodarczy i stopa bezrobocia w Niemczech w latach 1995-2009

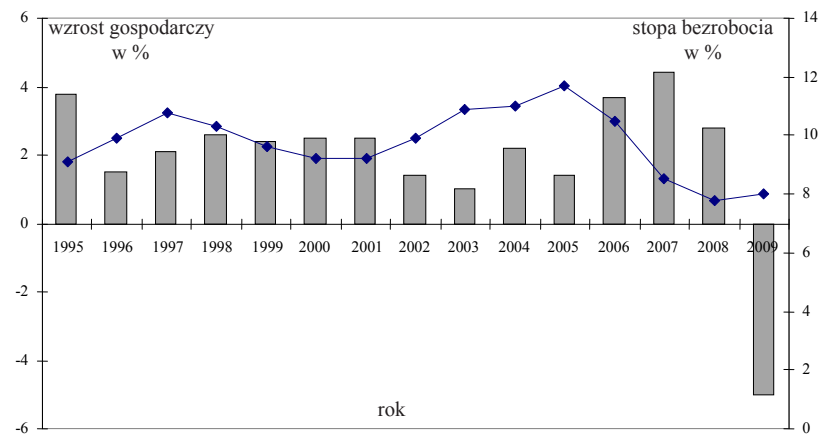

Dane na rok 2009: stopa bezrobocia po 2 kwartałach, prognozowany wzrost gospodarczy Źródło: Arbeitsmarkt 2007 (2008), Bundesagentur für Arbeit, Nürnberg; Der Arbeits- und Ausbildungsbericht für Deutschland. Monatsbericht September 2009, (2009), Bundesagentur für Arbeit, Nürnberg; Handelsblatt, http://www.handelsblatt.com/politik/konjunktur-nachrichten/; Volkswirtschaftliche Gesamtrechnungen, (2009), Statistisches Bundesamt, Fachserie 18, Reihe 1.5. Inlandsproduktrechung. Lange Reihen ab 1970, Wiesbaden. 
Podejmowane inicjatywy wprowadzenia i urzeczywistnienia w Niemczech założeń idei flexicurity nie odnoszą jeszcze spodziewanych efektów, postulowana elastyczność form zatrudnienia nie idzie w parze z zamierzonym bezpieczeństwem socjalnym (por. Jodkowska, 2009). Nadal rygorystyczna procedura zwolnień zapewnia pracownikom długi okres wypowiedzenia, a także / lub odprawy finansowe. $Z$ ankiet przeprowadzanych wśród pracodawców wynika jednoznacznie, że ochrona przed zwolnieniami wpływa najbardziej na rezygnację z zatrudnienia nowego pracownika. Dotychczasowe zmiany ukierunkowane na bardziej elastyczne formy pracy stwarzają przede wszystkim niekorzystną sytuację dla zatrudnionych (umowy o pracę na czas określony, zatrudnienie w niepełnym wymiarze czasu pracy).

Jednocześnie wywołuje to dyskusje między zwolennikami wynagrodzeń minimalnych ${ }^{3}$ a związkami przedsiębiorców argumentujących, że tylko przez obniżanie kosztów produkcji towary niemieckie są i mogą pozostać konkurencyjne na rynkach światowych ${ }^{4}$. Wzrastają realizowane przez koncerny zyski i wynagrodzenia managerów i powiększają się nożyce między najlepiej i najgorzej zarabiającymi, a także obie te grupy powiększają się ilościowo ${ }^{5}$. Realnie od kilku lat nie było podwyżek płac, zyski koncernów jednak stale rosły. Wymuszone na robotnikach i pracownikach tzw. rundy zerowe ${ }^{6}$ (Nullrunde) w ramach programów mających zabezpieczyć miejsca pracy doprowadziły realnie do obniżenia się wynagrodzenia ${ }^{7}$ (po odliczeniu inflacji). Uwzględniając rozwój cen $(1,1 \%-2 \%)$ realny poziom wynagrodzenia brutto obniżył się o $4,8 \%$ (średnio z $24873 €$ do $23684 €$ ) (Lebenslagen in Deutschland, 2009, s. 12). Spowodowane jest to m.in. zmniejszeniem się odsetka przedsiębiorstw związanych płacowymi umowami taryfowymi oraz przyrostem liczby osób zatrudnionych na niskopłatnych stanowiskach pracy. Na sytuację dochodową ludności negatywnie wpływa

${ }^{3}$ Niemcy są jedynym krajem w UE, w którym wynagrodzenie minimalne obowiązuje tylko dla nielicznych zawodów.

${ }^{4}$ Włącznie z 2008 r. Niemcy były pierwszym światowym eksporterem. Dopiero globalny kryzys finansowo-gospodarczy przyczynił się do utraty tego miejsca na rzecz Chin w $2009 \mathrm{r}$.

${ }^{5}$ Jeszcze w latach 90. XX w. wynagrodzenia członków zarządu 100 największych niemieckich koncernów były średnio o 15-20 razy wyższe niż średnie wynagrodzenia wszystkich innych pracowników. W 2005 r. wynagrodzenia członków zarządu były średnio o 43 razy wyższe od pozostałych wynagrodzeń. Por. J. Hirzel (i. in.) Denn wir wissen nicht, was sie tun, „Focus” 2007, nr 35, s. 65.

${ }^{6}$ „Runda zerowa” oznacza zachowanie miejsc pracy w danym momencie w danym przedsiębiorstwie przy rezygnacji zatrudnionych z podwyżki płac. Negocjacje te prowadzone są między związkami zawodowymi a związkami pracodawców i mają na celu utrzymanie poziomu zatrudnienia.

${ }^{7}$ Robotnik (45-letni brygadzista) zarabiający w 2000 r. $3055 €$ brutto (5.975 DM) odprowadzał $1064 €$ na składki oraz podatki i uzyskiwał wynagrodzenie netto $2113 €$. W 2005 r. po podwyżkach uzyskał $3800 €$ brutto, ponieważ w międzyczasie wzrosły pozapłacowe obciążenia płacy $(1735 €)$. Po siedmiu latach jego dochód wzrósł netto o $22 €(2135 €)$. Por. D. Deckstein, J. Tietz, Geld her, „Der Spiegel” 2007, Nr. 2, s. 59. 
także wysokie obciążenie podatkowe, wyższe od średniej krajów OECD, oraz tzw. zimna progresja podatkowa (przy podwyższeniu wynagrodzenia jego obciążenie podatkowe wzrasta na tyle, że przewyższa realną wartość podwyżki). Sytuacja ta jest niekorzystna z punktu widzenia polityki społecznej, ponieważ te niskie dochody nie zapewnią wystarczających środków na przeżycie i wymagają dopłat odnośnych urzędów ${ }^{8}$.

\section{NOWE FORMY ZATRUDNIENIA}

Nowe formy zatrudnienia w rozumieniu niniejszego opracowania to te, które nie są pełnoetatowym zatrudnieniem podlegającym obowiązkowym składkom na ubezpieczenia społeczne. Rozwój i popyt na te formy zatrudnienia został ułatwiony z jednej strony przez inicjatywę ,aktywizująca rola państwa” i reformę zasiłków dla bezrobotnych (wprowadzenie Minijob i Midijob), a z drugiej strony przez dążenie do wdrożenia europejskiej idei flexicurity oraz przez zmiany zachodzące w zapotrzebowaniach pracodawców, np. krótkotrwałe zwiększenie liczby pracowników ze względu na wolumen zleceń. Te zapotrzebowania zaspokajane są przede wszystkim przez prywatne pośrednictwa pracy, w tym także te specjalizujące się w „wypożyczaniu pracowników” na określony czas. Nietypowe formy zatrudnienia (niepełnoetatowe i niejednokrotnie niezapewniające środków na godną egzystencję) przyjęło się określać w Niemczech „niepewnymi stosunkami pracy" (prekäre Beschäftigungsverhältnisse ${ }^{9}$ ).

W ramach wprowadzania nowoczesnych usług na rynku pracy już w $2003 \mathrm{r}$. usankcjonowano $\mathrm{w}$ nowy sposób zatrudnienie $\mathrm{w}$ niepełnym wymiarze pracy wprowadzając instrumenty zwane minietatem (Minijob) i etatem midi (Midijob). W zamierzeniu reformatorów miały się one przyczynić do obniżenia bezrobocia, zwłaszcza wśród osób niewykwalifikowanych.

Wcześniejsze przepisy określały minietat jako zatrudnienie z wynagrodzeniem do $325 € /$ mies. o maksymalnie 15 godzinnym tygodniu pracy. W chwili obecnej wynagrodzenie w ramach minietatu może wynosić maksymalnie do 400 $€ /$ mies. Ta forma zatrudnienia nie podlega nadal opodatkowaniu, podlega natomiast składce na ubezpieczenie emerytalne i jest zaliczana do okresu zatrudnienia. W latach wcześniejszych te okresy nie były zaliczane do emerytury. W praktyce jest to forma zatrudnienia, z której korzystają także osoby zatrudnione na pełnym etacie w celu dorobienia, w takich przypadkach możliwy jest tylko jeden minietat. Osoby zatrudnione na kilku minietatach jednocześnie, które otrzymują wynagrodzenia powyżej $400 € /$ mies., podlegają wszystkim ubezpieczeniom

${ }^{8}$ Świadczeń dla pracujących, których dochód nie wystarcza na podstawowe potrzeby udziela Jobcenter.

${ }^{9}$ Prekär $\mathrm{w}$ tym znaczeniu pochodzi od francuskiego słowa précaire i łacińskiego precarius. 
społecznym, tj. obok składek na ubezpieczenie emerytalne odprowadzane są także składki na ubezpieczenie chorobowe, opiekuńcze i na wypadek bezrobocia. Wprowadzenie minietatów miało zapobiegać zatrudnianiu w szarej strefie, w szczególności w gospodarstwach domowych zatrudniających np. opiekunki do dzieci i gospodynie domowe.

Wraz z minietatem wprowadzono także etat midi (Midijob). Jest to niskopłatne zatrudnienie, pomiędzy 400,01 i 800,00 €. Dla płacy powyżej $325 €$ składki na ubezpieczenia społeczne znacznie się zwiększały (z 22 do 40\%). Obecnie dla etatu midi opłaty te wzrastają linearnie (przy wynagrodzeniu wynoszącym $400 € /$ mies. $11 \%$, przy $800 € /$ mies. $21 \%$ ). Dla bezrobotnych ten rodzaj pracy jest mało atrakcyjny, ponieważ otrzymywane wynagrodzenie jest równe lub niewiele wyższe od otrzymywanych zasiłków.

Silne związki zawodowe i dwu- lub trójstronne porozumienia płacowe w niektórych branżach (przede wszystkim w klasycznych przedsiębiorstwach przemysłowych reprezentujących zawody typowe na mężczyzn) doprowadziły do dużej rozpiętości wynagrodzenia na godzinę. Wysokiemu wynagrodzeniu w przemyśle (ok. $28 € /$ godz.), zwłaszcza metalurgicznym, podlegającym pod zbiorowe umowy taryfowe związków zawodowych IG-Metall, odpowiada niskie wynagrodzenie w usługach ( $3-5 € /$ godz.); $4,95 € /$ godz. we fryzjerstwie; $5,12 € /$ godz. w prywatnym transporcie; 4,71-5,15€/godz. w ogrodnictwie, 5,18 €/godz. w hotelarstwie; $5,75 € /$ godz. przy ochronie obiektów. Sytuacja podobnie kształtuje się dla niektórych innych zawodów, np. 5,32 €/godz. dla ślusarzy i mechaników, 5,59 €/godz. dla rzeźników. W handlu i w prywatnych agencjach pracy obowiązują stawki poniżej 7,20 €/godz. Porównując te stawki i uzyskiwany dochód z wysokością zasiłku Hartz IV przeliczonego na godzinę zatrudnienia (dla pary bezdzietnej, włącznie z opłatą za mieszkanie) ok. 7,59 €/godz. konkluzja jest jednoznaczna - podjęcie pracy w niektórych przypadkach pogarsza sytuację dochodową (Klawiter, 2007, s. 69; Knaup, Sauga, 2007, s. 26). Zwłaszcza niewykwalifikowani robotnicy (tzw. proletariat usługowy), osoby rozpoczynające karierę zawodową (generacja praktykantów / Generation Praktikum ${ }^{10}$ ), mniejszości narodowe oraz kobiety, w szczególności te po urlopach macierzyńskich, zatrudniani są na niskopłatnych stanowiskach pracy. Te grupy osób wpadają w tzw. pułapkę państwa socjalnego polegająca na tym, że uzyskane świadczenia mogą być wyższe od dochodu uzyskanego z pracy zarobkowej, czym odbierają

${ }^{10}$ Zdobywanie praktycznych umiejętności po studiach w celu podwyższenia jakości wykształcenia przeobraziło się w ostatnich latach w formę zatrudnienia. W latach 1999-2004 wartość zarejestrowanych miejsc praktyki dla absolwentów w zakładach wzrosła o 141\%. Nie oddaje to jednak pełnego obrazu sytuacji, praktyki nie zawsze objęte są rejestracją, zwłaszcza kiedy są nieodpłatne - co zdarza się coraz częściej. Pracodawcy korzystają w okresie praktyk z kwalifikacji absolwentów i odwlekają zatrudnienie ich. Por. M. Mörchen (2006), Praktikum als prekäre Beschäftigung - Ausbeutung oder Chance zur Integration?, Kooperationsstelle Wissenschaft-Arbeitswelt im Landesinstitut Sozialforschungsstelle, s. 8, 10. 
motywację do podjęcia pracy ${ }^{11}$. Edmund S. Phelps, laureat nagrody Nobla w dziedzinie ekonomii w 2006 r., uważa, że transfery społeczne pogarszają problem marginalizacji niskopłatnych pracowników, ,ponieważ osłabiając motywację, tworzą kulturę uzależnienia i wyalienowania z komercyjnej gospodarki, zmniejszają udział beneficjentów w sile roboczej, obniżają ich atrakcyjność dla pracodawców i osłabiają lojalność pracobiorców. Zatrudnienie i płace trzeba zwiększyć, tworząc wyższy popyt na najmniej wydajnych pracowników." (Dotacje, które ratuja ludzi, 2006, s. B-7).

Dwa nowe hasła związków zawodowych Arm durch Arbeit (biedny przez pracę) i Arm trotz Arbeit (biedny pomimo pracy), a także obecny kryzys gospodarczo-finansowy wpływają już w chwili obecnej na zwiększenie się liczby ich członków. R. Blundell uważa, że zmniejszenie znaczenia związków zawodowych (ograniczenie negocjacji płacowych) doprowadziłoby do zmniejszenia się bezrobocia. Czerpiąc doświadczenia z systemu brytyjskiego, przestrzega, że ,jeśli związki zawodowe negocjują warunki zatrudnienia i płac, to wystapi zbyt mała podaż pracy według aktualnej stawki płacowej”. Prowadzi to wg niego do sytuacji, w której nie wszyscy zainteresowani podjęciem pracy ofertę pracy uzyskają. Konsekwencją tych negocjacji jest ograniczenie zatrudnienia (R. Blundell, 2007, s. 175-176). Potwierdza się to częściowo na niemieckim rynku pracy dla przedsiębiorstw związanych umowami płacowymi.

W latach 1995-2006 wzrósł udział pracowników na stanowiskach niskopłatnych (wynagrodzenie poniżej 2/3 mediany) wśród wszystkich zatrudnionych z $15 \%$ do $22 \%$ (Kalina, Weinkopf, 2009, s. 1). Wynagrodzenie brutto za godzinę o wysokości do $6,81 € \mathrm{w}$ landach wschodnich i 9,61 $€$ w landach zachodnich jest granicą zatrudnienia na stanowiskach niskopłatnych (ibidem s. 3). W porównaniu z innymi krajami na stanowiskach niskopłatnych w Niemczech zatrudnieni są głównie pracownicy z wykształceniem co najmniej zawodowym $(75 \%)^{12}$, co wypiera $\mathrm{z}$ rynku pracy osoby niewykwalifikowane i spycha je w dół drabiny dochodowej.

Mimo transferów społecznych grupami najbardziej zagrożonymi ubóstwem są bezrobotni oraz rodziny z dziećmi, a także w szczególności osoby samotnie wychowujące dzieci. Wystąpił także przyrost zagrożenia ubóstwem w grupie osób pracujących. Jednym z powodów tego rozwoju jest zmniejszenie się udziału zatrudnionych $\mathrm{w}$ przedsiębiorstwach związanych porozumieniami płacowymi (umowami taryfowymi) z 70\% w 1998 r. do 54\% w 2005 r., co umożliwiło pracodawcom obniżenie stawek godzinowych (Lebenslagen in Deutschland, 2009,

${ }^{11}$ Suma świadczeń uzyskiwanych przez małżeństwo z dwojgiem dzieci włącznie z dodatkiem na mieszkanie wynosi ok. $1600 € /$ mies., wynagrodzenie brutto po stawce $7 € /$ godz. wynosi $1120 €$. Przy założeniu, że pracujący ojciec jest jedynym żywicielem rodziny niezbędne są uzupełniające świadczenia odnośnych urzędów.

${ }^{12}$ W 1995 r. bez wykształcenia 33,5\%, z wykształceniem zawodowym 58,6\% i 7,9\% z wykształceniem akademickim, w 2006 r. analogicznie 26,4\%, 67,5\%, 6,1\% (,Focus”, s. 87). 
s. 76). Powoduje to zmniejszanie się klasy średniej ${ }^{13}$. W latach 80 . XX w. należało do niej $85 \%$ obywateli BRD, po zjednoczeniu Niemiec $60 \%$ społeczeństwa (49 mln osób). Do 2006 r. grupa ta zmniejszyła się do 54\% (44 mln osób) (Mittelschicht, „Focus” 2008/28, s. 86). Dynamicznie wzrastają dochody górnych decyli dochodowych (rosnąca koncentracja), dolnych wykazują tendencję stagnacyjną lub nawet negatywną przy jednoczesnym zwiększającym się dystansie pomiędzy dochodami górnych i dolnych decyli. Problemem jest nadal podział kraju - obok tradycyjnego, pochodzącego jeszcze z okresu RFN na bogatsze południe i biedniejszą północ, na bardziej zagrożony ubóstwem wschód i mniej zagrożony ubóstwem zachód. Największe zagrożenie ubóstwem występuje w landzie Meklemburgia Pomorze Przednie $(24,3 \%)$ oraz Saksonia Anhalt $(21,5 \%)$, równie negatywna sytuacja panuje w pozostałych landach wschodniej części Niemiec (od 17,5\% w Berlinie i Brandenburgii po 19,6\% w Saksonii). Gospodarczo mocne kraje południa Niemiec, takie jak Bawaria czy Badenia Wirtembergia oraz Hesja wykazują najmniejsze zagrożenie ubóstwem (od 10\% do 12\%) i osiągają najwyższe wartości PKB na mieszkańca (Martens, 2009, s. 47-50).

Oferowane niskopłatne stanowiska pracy stwarzają nowe problemy socjologiczne (ponownie pojawiło się zagadnienie klas, w znaczeniu klas zawodowych) i psychologiczne, związane z niepewnością jutra: niepewność dotycząca pozostania na danym stanowisku, obawa przed obniżeniem statusu społecznego, brak możliwości planowania przyszłości, brak możliwości oszczędzania ze względu na niskie zarobki, ryzyko utraty pracy.

Przebywanie pracowników na stanowiskach stałych i krótkoterminowych w jednym zakładzie pracy stwarza także niekomfortową sytuację dla tych pierwszych. Potwierdziły to badania przeprowadzone w koncernie Audi i w wybranych niemieckich bankach, w których zatrudnieni są tzw. freelancer ${ }^{14}$. Pracownicy na stanowiskach stałych odczuwali dyskomfort, ponieważ widzieli bezpośrednie zagrożenie swojego zatrudnienia i możliwość zastąpienia pracownikiem tańszym.

\section{ZAKOŃCZENIE}

Z socjologicznego punktu widzenia można potraktować pracę jako narzędzie socjalizacji obywateli, z filozoficznego jako źródło zadowolenia, natomiast z ekonomicznego punktu widzenia praca powinna spełniać funkcję pragmatyczną, opierającą się na założeniu, że dochód z pracy umożliwia pracownikowi i jego

\footnotetext{
${ }^{13}$ Klasa średnia została zdefiniowana przez Institut der Deutschen Wirtschaft (DIW) jako osoby z dochodem pomiędzy 70 a $150 \%$ mediany (w przypadku rodzin odpowiednio na każdego członka rodziny).

${ }^{14}$ Są to osoby przeprowadzające projekty na zlecenie i niezatrudnione w danej firmie.
} 
rodzinie prowadzenie godnego życia. Popyt na niskopłatne stanowiska pracy na pełnym lub niepełnym etacie prowadzi do powiększającego się rozwarstwienia dochodowego w Niemczech. Zwłaszcza w ostatniej dekadzie wzrósł udział niskopłatnych stanowisk pracy, z których dochód utrzymuje się niejednokrotnie na poziomie możliwego do uzyskania zasiłku. Zatrudnieni na tych stanowiskach wykwalifikowani robotnicy zastąpili dotychczas wykonujące najprostsze prace osoby niewykwalifikowane, wypierając je z rynku pracy. Jest to trend występujący na całym świecie. Wzrost wartości dodanej gospodarek odbywa się w dużej mierze w sferze idei, co powoduje coraz mniejsze zapotrzebowanie na niewykwalifikowanych pracowników, a coraz większe na osoby dobrze wykształcone.

Wysoki wskaźnik zatrudnienia utrzymuje się nadal mimo dużo trudniejszej sytuacji na rynku pracy w 2009 r. Mimo globalnego kryzysu finansowo-gospodarczego nie wystapił przyrost stopy bezrobocia, choć możliwe jest jeszcze wystąpienie regresu w 3 lub 4 kwartale 2009 r. Integracja bezrobotnych z grup wiekowych poniżej 25 lat oraz powyżej 55 lat potwierdza pozytywny efekt przeprowadzonych reform. Pozytywnie należy także ocenić zobowiązanie bezrobotnych do podjęcia aktywniejszych starań o znalezienie pracy.

Zwiększenie elastyczności form pracy odbywa się kosztem pracowników bez zapewnienia należytego bezpieczeństwa socjalnego. Przemieszanie pracowników na stanowiskach stałych i tych z, wypożyczalni” (Leiharbeiter) odbywa się często za przyzwoleniem związków zawodowych, aby chronić interesy płacowe tych pierwszych.

Zaistniałe zmiany na rynku pracy można ocenić w dwóch kategoriach: negatywnie z punktu widzenia pracownika (niepewność, obciążenie psychiczne, dochód niewystarczający na godną egzystencję) oraz pozytywnie z punktu widzenia pracodawców (odejście od porozumień płacowych i obniżenie stawek godzinowych zapewnia im elastyczność w podejmowaniu decyzji w zależności od sytuacji na rynku).

\section{LiTERATURA}

Arbeitsmarkt 2007 (2008), Bundesagentur für Arbeit, Nürnberg.

Blundell R. (2007), Podaż pracy a opodatkowanie, [w:] Devereux M. (red.), Efektywność polityki podatkowej, Wydawnictwo Sejmowe, Warszawa.

Borkowski T., Marcinkowski A. (1996), Socjologia bezrobocia, Wydawnictwo Interart, Warszawa

Deckstein D., Tietz J. (2007), Geld her, „Der Spiegel” 2007, Nr. 2.

Die „Hartz-Reform“ und ihre Folgen. Forschungsimpulse für eine innovative und sozialgerechte Arbeitsmarktpolitik, Hans Böckler Stiftung, Düsseldorf 2006

Der Arbeits- und Ausbildungsbericht für Deutschland. Monatsbericht September 2009, (2009), Bundesagentur für Arbeit, Nürnberg.

Dotacje, które ratuja ludzi (2006), „,Rzeczpospolita”, z 10.10.06. 
Handelsblatt, http://www.handelsblatt.com/politik/konjunktur-nachrichten/.

Hirzel J. (2007), Denn wir wissen nicht, was sie tun, „Focus” 2007, Nr 35.

Institut der Deutschen Wirtschaft, http://www.iwkoeln.de/.

Jodkowska L. (2008), Wpływ polityki spotecznej państwa opiekuńczego na wzrost gospodarczy i stope zatrudnienia w Polsce $i$ w Niemczech, http://www.ae.katowice.pl/images/user/ File/katedra_ekonomii/-L.JODKOWSKA_WPLYW_POLITYKI_SPOLECZNEJ_PANSTWA_OPIEKUNCZEGO_NA_WZROST_GOSPODARCZY_I_STOPE_ZATRUDNI. pdf.

Jodkowska L. (2009), Państwo opiekuńcze a idea flexicurity, „Ekonomista” 2009, nr 2.

Kalina T., Weinkopf C. (2009), Niedriglohnbeschäftigung 2007 weiter gestiegen - zunehmende Bedeutung von Niedriglöhnen, IAQ-Bericht 2009-05, Institut Arbeit und Qualifikation, Essen 2009.

Klawitter N. (2007) Vorindustrielle Ausbeutung, „Der Spiegel” 2007, Nr 2.

Knaup H., Sauga M. (2007) Radikaler Neuanfang, „Der Spiegel” 2007, Nr 2.

Kurz K., Wittke V., Die Nutzung industrieller Kapazitäten in Mittelosteuropa durch westliche Unternehmen - Entwicklungspfade einer neuen industriellen Arbeitsteilung (1998), SOFI-Mitteilungen 1998, Nr 26.

Lebenslagen in Deutschland. Der 3. Armuts- und Reichtumsbericht der Bundesregierung (2009), Bundesministerium für Gesundheit und Soziale Sicherung, Bonn.

Martens R. (2009), Unter unseren Verhältnissen, Der erste Armutsatlas für die Regionen Deutschland, Paritätische Forschungsstelle.

Mittelschicht (2008), „Focus” 2008, Nr 22.

Mörchen M. (2006), Praktikum als prekäre Beschäftigung - Ausbeutung oder Chance zur Integration? Kooperationsstelle Wissenschaft-Arbeitswelt im Landesinstitut Sozialforschungsstelle.

Sozialbericht 2005 (2005), Bundesministerium für Gesundheit und Soziale Sicherung, Bonn. Sozialbericht 2009 (2009), Bundesministerium für Arbeit und Soziales, Bonn.

Soziale Sicherung im Überblick (2006), Bundesministerium für Arbeit und Soziales, Bonn. Statistisches Bundesamt, http://www.destatis.de.

Volkswirtschaftliche Gesamtrechnungen (2009), Statistisches Bundesamt, Fachserie 18, Reihe 1.5. Inlandsproduktrechung. Lange Reihen ab 1970, Wiesbaden. 


\title{
Labour MARKet IN GeRmany in THE YeARs 2000-2009
}

\section{- NEW FORMS OF EMPLOYMENT}

Key words: labour market, low-paid jobs, temporary workplaces

\begin{abstract}
The aim of the paper is to present the situation on the German labor market after the year 2000 using data analysis and their graphic presentation as well as description of new forms of employment. The paper consists of 2 parts, introduction and conclusion. In part one the situation on the labor market was presented with regard to the employment rate and unemployment rate in the years 2000-2009 taking into account the reforms of unemployment benefits (2005). In part two of the paper these new forms of employment were described (Minijob, low-paid jobs, temporary workplaces) that in recent years have been competing with and displacing permanent employment, providing employers with the necessary flexibility, especially important during crisis. Description of these forms of employment was extended by the analysis of poverty risk among groups of workers with low-paid jobs and temporary workplaces. In the conclusion, there is a summary of the trends that are apparent on the labor market and of the changes caused by them in the financial situation of the workers.
\end{abstract}

